\title{
Guerrilla urbanism: urban design and the practices of resistance
}

\author{
Jeffrey Hou ${ }^{1}$ \\ Published online: 19 February 2020 \\ (c) Springer Nature Limited 2020
}

\begin{abstract}
Unsanctioned, unscripted, and seemingly "undesirable" activities have long appropriated urban spaces in routine and sometimes unexpected ways, bringing new meanings and unforeseen functions to those places. In the last decade or so, such practices have inspired a growing movement under the banner of DIY and tactical urbanisms. The growing acceptance of these practices creates important openings in the formalized planning systems for greater flexibility and expedient change. Yet, the institutionalization of previously informal and even subversive acts has resulted in concerns regarding co-optation and de-politicization. This special issue seeks to pivot a refocus towards these unsanctioned and unscripted urban activities as a form of counter-hegemonic spatial practices, distinct from its professionalized and institutionalized counterpart. A range of cases is examined here sharing similar characteristics as challenges against the prevailing social and political paradigm. Key findings include the scalability of guerrilla actions, the fluid shift between overt and covert actions, and the linkage between everyday struggles and organized resistance. This special issue is intended to advance our understanding of urban design by situating it in a broader social, economic, and political praxis that encompasses both formal and informal practices performed by a wide variety of individual and collective actors.
\end{abstract}

Keywords Guerrilla urbanism · Tactical urbanism · Insurgent planning $\cdot$ Spatial practices $\cdot$ Everyday resistance

Unsanctioned, unscripted, and seemingly "undesirable" activities have long been a part of urban life. Their innumerable variations include street vending, graffiti writing, skateboarding, squatting, guerrilla gardening, political protests, and countless other unintended and sometimes unimaginable uses. They occupy or appropriate urban spaces in routine and sometimes unexpected ways, bringing new meanings and unforeseen functions to those places. In many cities around the world, these activities are an integral part of the quotidian urban landscapes and systems of everyday life. Street vendors, for example, appropriate street corners and sidewalks on a daily basis to provide basic and necessary services to the urbanites. Children, teenagers, and even adults turn vacant lands into playgrounds of different sorts. Protestors occupied streets, plazas, and even expressways and airport terminals to make their voices heard. Graffiti writers and artists assign meanings and symbols and offer commentaries on the city. On one hand, these activities

Jeffrey Hou

jhou@uw.edu

1 University of Washington, Box 355734, Seattle, WA 98195-5734, USA have been an important part of the economic and social life of a city. On the other hand, they may result in tensions and disruptions with the intent to mobilize action and bring attention to particular social, economic and political issues. Together, they encompass both short-term, temporary actions and lasting struggles and contestations.

Over the last few decades, there has been a growing body of literature that examines these activities and processes through different conceptual lenses, including everyday urbanism (Chase et al. 1999), invented and invited spaces of citizenship (Miraftab 2004), loose space (Franck and Stevens 2007), urban pioneering (Overmeyer 2007), the temporary city (Bishop and Williams 2012), temporary urban spaces (Hayden and Temel 2006), guerrilla urbanism (Hou 2010), tactical urbanism (Lydon and Garcia 2015), and do-it-yourself urbanism (Iveson 2013; Douglas 2014, 2018; Finn 2014). Along with their popularity, there has also been a growing acceptance of these approaches by institutional actors including local governments, developers, and urban design professionals. Under the banners of tactical urbanism, creative placemaking, pop-up, and so on, improvised uses of urban spaces have become a method of urban design interventions and even development strategies. Increasingly, these temporary 
and tactical interventions have become a normative and even fashionable component of the technocratic repertoire in activating urban spaces and properties.

The growing acceptance of these practices, on the one hand, creates important openings in the rigid, formalized planning systems for greater flexibility and expedient change. Yet, the institutionalization of previously informal and even subversive acts has resulted in concerns regarding co-optation and depoliticization, particularly in the context of prevailing neoliberal governance (Mould 2014; Brenner and Theodore 2003). While it's important and necessary to debate the implications and efficacy of the DIY and tactical urban design, such attention seems to have overshadowed critical questions concerning their counterparts - the unsanctioned, guerrilla urban tactics as a form of insurgent spatial practice against the prevailing social and political conditions. For instance, what can unsanctioned, guerrilla actions by the underprivileged and the disenfranchised tell us about the conditions and barriers in the contemporary city? How can these individually small-scale, bottom-up actions lead to substantive transformation in urban landscapes? How can actions of resistance result in institutional and political change without becoming subsumed by it? How are unsanctioned actions relevant to the discourse and practice of urban design in ways that are distinct from the accepted forms of tactical urbanism?

These questions deserve greater attentions, especially as the concerns for equity and justice have again come to the forefront in professional and public discourses in the face of gentrification, displacement, and neoliberal governance. This special issue of Urban Design International invited leading and emerging scholars to offer their insights through in-depth case studies and evidence-based discussions. Specifically, this issue seeks to pivot a refocus towards guerrilla urbanism as a form of counter-hegemonic spatial practices, distinct from its professionalized and institutionalized counterpart, namely tactical urbanism. A range of cases is examined here that share similar characteristics as unsanctioned activities and as challenges against the institutional authority and the prevailing social and political paradigm. Perspectives from both the Global South and North are represented here to the extent possible given the limited space. With this collection of work, this special issue is intended to advance our understanding of urban design by situating it in a broader social, economic, and political praxis that encompasses both formal and informal practices performed by a wide variety of individual and collective actors.

\section{Tactical urbanism and its discontents}

Aside from their esthetic appeals and ability to be easily implemented, the recent rise of short-term urban interventions has been associated with prevailing conditions of neoliberal governance in cities and societies around the world. Specifically, with diminishing public investment in urban infrastructure and amenities, citizens and communities have resorted to actions that serve as expressions of both self-help and resistance against the prevailing political and market conditions. In his study of DIY urban interventions, Douglas (2014, pp. 10-11) sees these actions, including guerrilla gardening and unauthorized street improvements, as "direct responses to the perceived neglect of some spaces." Webb (2018, p. 58) argues that the economic crisis has brought various forms of informal urbanism, "aimed at influencing the future shape of places as well as the way they are governed.” Specifically, “[a] weakened climate for private investment has created opportunities for small-scale entrepreneurs, collectives and community enterprises, with a range of low-capital land uses from urban agriculture to pop-up shops to food trucks all becoming more prevalent" (Webb 2018, p. 58).

Citizens and communities are not the only ones responding to these conditions. Webb (2018) suggests that the neoliberal austerity across the Western economies, combined with weak economic recovery since 2008 , is forcing a shift in terms of how development has been approached by private developers. Specifically, he argues, "developers are facing increased risks and the use of temporary interventions is becoming more appealing as a way of testing out change" (Webb 2018, p. 58). The acceptance of temporary urbanism as a legitimate planning approach reflects the realization that outcomes of large-scale developments can no longer be planned or predicted (Von Seggern and Werner 2008), and that the resources for implementing formal master plans are no longer available (Bishop and Williams 2012). For many local municipalities, the creative esthetic of these temporary inventions presents an appealing factor for incorporation into frameworks of urban redevelopment, making it "the latest iteration of 'cool', creative urban policy language" and "the latest political vernacular of the Creative City" (Mould 2014, pp. 529, 530).

Once considered as marginalized activities outside the legal domain, temporary interventions are increasingly recognized as a legitimate and desirable tool for activating underutilized sites in the city (Hou 2016). The introduction of tactical urbanism as a planning method played an important role in this transformation. As envisioned by its proponents, tactical urbanism represents "an approach to neighborhood building and activation using short-term, lowcost, and scalable interventions and policies" (Lydon and Garcia 2015, p. 2). Unlike the previous focus on individual and collective self-help, tactical urbanism can be carried out by institutional actors, including municipal agencies and nonprofit organizations alike. "Tactical Urbanism does not consist solely of unsanctioned activity carried out under the cloak of the night," argued Lydon and Garcia (2015, p. 8). 
Instead, the so-called tacticians are "found from the bottom up, the top-down, and everything in between" (The Street Plans Collaborative in Lydon and Garcia 2015, p. 11).

The integration of informal tactics and institutional practices under tactical urbanism, however, has led to a series of criticisms (see Mould 2014; Douglas 2014, 2018; Campo 2016; Silva 2016). Specifically, Silva (2016, p. 1049) identifies an inherent contradiction between the spirit of tactical urbanism- "something that is non-hierarchical, with very simple targets, sometimes leading to unexpected results," with the goal-oriented, hierarchical spatial planning structures. Webb (2018) articulates a suspicion concerning the migration of counter-hegemonic actions to arenas of urban design consultancy. Through political co-optation, Mould (2014, p. 532) suggests that these activities are being "subsumed into the wide process of urban capitalism (despite being predicated upon a reaction against it)." Despite its activist origins and even subversive nature, Mould (2014) argues that tactical urbanism is becoming co-opted by the neoliberal development agenda. Similarly, in a review of the book Tactical Urbanism by Lydon and Garcia (2015), Campo (2016, p. 389) concludes that tactical urbanism is "a counter-urbanism well-positioned for the neoliberal world and can be incorporated into larger and more traditional planning initiatives." Vallance et al. (2017) further argue that in its goal to improve formal plans, policies and procedures, the 'insurgent' or 'revolutionary' potential of tactical urbanism has become limited.

\section{Understanding and unpacking everyday resistance}

While actions or initiatives under the banner of tactical urbanism have consumed much of recent professional and academic discourses, other forms and manifestations of guerrilla urban actions have continued to flourish in cities and places around the world. One may argue that the number of interventions branded under tactical urbanism is most likely minute compared with the actual unsanctioned and unscripted activities performed by the subaltern and underprivileged in their everyday struggles for livelihood. In light of their sheer magnitude and collective significance, how can we better understand these guerrilla struggles as a form of contention and spatial practices? Through what ways do they challenge or circumvent the dominant or oppressive structure in the society and the built environment? Where do they intersect with the practices of urban design? Or, how can we view them perhaps as a form of insurgent practices in urban design?

Over the past few decades, a significant body of work has offered insights on these informal and insurgent practices in fields ranging from anthropology and sociology to philosophy and political science. Most notably, in The Practices of Everyday Life, Michel de Certeau (1984) pursues an inquiry into what he calls "ways of operating" by the dominated or "users" as distinguished from "makers." $\mathrm{He}$ suggests, "We must first analyze [the] manipulation by users who are not its makers. Only then can we gauge the difference or similarity between the production of the image and the secondary production hidden in the process of its utilization" (de Certeau 1984, p. xiii). Evoking Michel Foucault's (1977) conceptualization in Discipline and Punish, de Certeau (1984, p. xiv) seeks to illuminate "the clandestine forms taken by the dispersed, tactical, and makeshift creativity of groups or individuals caught in the nets of 'discipline'." Using the practices of indigenous people under Spanish colonization as an example, he argues that the indigenous subjects subvert the rituals, representation, and laws under the colonization "not by rejecting or altering them, but by using them with respects to ends and references foreign to the system" (de Certeau 1984, p. xiii). He further argues that "the ingenious ways in which the weak make use of the strong, thus lend a political dimension to everyday practice" (de Certeau 1984, p. xvii).

In another seminal work, Weapons of the Weak, Scott (1985) conceptualizes the minor but persistent struggles of the subordinate class against the exploitation of the state or the dominant class as "everyday forms of resistance." Examples of their ordinary weapons include the following: "foot-dragging, dissimulation, desertion, false compliance, pilfering, feigned ignorance, slander, arson, sabotage, and so on" (Scott 1985, p. 29). As everyday forms of resistance, he argues, "[t]hey require little or no coordination or planning; they make use of implicit understandings and informal networks; they often represent a form of individual self-help; they typically avoid any direct, symbolic confrontation with authority" (Scott 1985, p. 29). In contrast to the formal and overt form of institutional politics focusing on systematic, de jure change, he further notes, "everyday resistance is informal, often covert, and concerned largely with immediate, de facto gains" (Scott 1985, p. 33). In a subsequent article, Scott (1989, p. 33) describes these actions as part of a vast realm of political action that is habitually overlooked: "much of the politics of the subordinate groups falls into the category of 'everyday forms of resistance,' that these activities should most definitely be considered as political that they do constitute a form of collective action..." He argues that while no formal organizations are created, tacit coordination exists through, for example, "a shared knowledge of the available techniques of evasion, and economic interest" (Scott 1989, p. 40).

More recently, in examining the contentious politics in the Middle East, Asef Bayat (2013, p. x) arrives at similar observations by looking into the sociopolitical transformation brought about by collectives and individuals, including 
"the subaltern, the urban dispossessed, Muslim women, the globalizing youth, and other urban grassroots." $\mathrm{He}$ argues that ordinary people can change their societies not by mass protests or revolution, but by resorting to what he calls "nonmovements" which he defined as "the collective actions of noncollective actors." Rarely guided by an ideology or recognizable leadership and organizations, nonmovements embody "shared practices of large numbers of ordinary people" whose fragmented but similar activities can trigger social change (Bayat 2013, p. 15). The activities include extralegal practices that infringe and subvert governing norms. He further suggests that "because they are part and parcel of everyday life, nonmovements assume far more resiliency against repression than the conventional activisms" (Bayat 2013, p. 21). However, unlike Scott's notion of everyday resistance which avoids outright collective confrontation, Bayat (2013, p. 27) argues that the nonmovements may turn into organized social movements when the opportunity arises, or return to "the more individual encroachments when the cost of organizing collective movements rises, or when the adversaries fail to respond to their collective pressure." In other words, nonmovements can be elevated to organized actions and collective defiance, or retreat if the conditions are longer favorable. They adapt dynamically to the shifting political opportunities and the changing cost of collective actions.

Between de Certeau (1984), Scott (1985, 1989), Bayat (2013), and others beyond the pages here, there exists a rich body of knowledge beyond the normative urban design theories. This body of knowledge is invaluable in deepening the discourse of guerrilla urban actions as performed by the disenfranchised and the underprivileged in their everyday and not-so-everyday struggles. It enables us to discern and articulate how the dominant structure of the society can be subverted, appropriated, or circumvented in ways that may be invisible to the state or the dominant class, or that they would not openly acknowledge. Given opportunities, these mostly dispersed and tacitly coordinated tactics can lead to organized actions and collective transformation.

\section{Beyond insurgencies in urban design and planning?}

In urban design and planning, discourses that address the everyday forms of resistance have emerged as well in recent decades. The literature has primarily looked at practices of resistance as an insurgent form of planning and design. In particular, Holston (1998) introduces the concept of insurgent citizenship to characterize the claims of subaltern society members, including the homeless, migrants and other marginalized social groups. With insurgent citizenship and insurgent urbanism as its spatial mode, Holsten (1998) calls for a rethinking of the social in planning, as rooted in the heterogeneity of lived experience, in contrast to the formalized, reductionist state institution. Similarly, Miraftab (2009, p. 43) proposes the notion of insurgent planning as a set of counter-hegemonic spatial and social practices by marginalized groups and as a counterpoint to the limited form of citizen participation that has become "the accomplice of neoliberal governance." Specifically, she describes insurgent planning practices as counter-hegemonic, transgressive, and imaginative. "[They] destabilize order of things; they transgress time and place by locating historical memory and transnational consciousness at the heart of their practices. They are imaginative in promoting the concept of a different world as being [...] both possible and necessary" (Miraftab 2009, p. 33).

My work over the past decade was intended to contribute to this literature as well. In Insurgent Public Space (Hou 2010), we examine the various ways through which citizens and communities have taken actions to appropriate, adapt, or create spaces of their own, often outside or at the border of the regulatory domain, in ways that are distinct from the production of institutional public space. In addition to challenging the predominant ordering of urban spaces and their associated codes, meanings, and protocols, these actions represent the agency and ability of people to transform the city (Hou 2010). In Transcultural Cities (2013), we focus on how places and placemaking serve as a vehicle for engendering cross-cultural understanding among individuals and communities of different cultural backgrounds in the context of migration and resettlement, and how these actions represent efforts in transforming not only urban places but also the relationships among their inhabitants. In Messy Urbanism (Chalana and Hou 2016), we examine how sites and activities created by the subaltern publics often possess an order and hierarchy visible and comprehensible only to their participants. Yet such spatial, temporal, and socioeconomic "messiness" has enabled communities to thrive in highly challenging contexts (Hou and Chalana 2016). "As cracks and fissures in the postpolitical, homogenous landscapes of contemporary cities," we argue that messiness "presents opportunities for a new epistemology of city and city-making; a mode of contestation, collaboration, and composition; and as a site for rethinking and untangling the difficult tasks of democracy, justice, and resilience" (Chalana and Hou 2016, p. 243).

The distinction between everyday resistance and organized struggles represents a specific observation echoed in the planning and design literature. Similar to the work of James C. Scott, Perera $(2009$, p. 52) looks at how those that exist in the margins, cracks, and interstices of the formal society "do not replace but provincialize and contextualize hegemonic spatial narrative." Rather than directly challenging the system of power, he argues that "they largely practice apathy 
or reluctant compliance, at the same time seeking to improve their livelihood within the context through the use of ordinary acts" (Perera 2009, p. 55). Conceptualizations like these have enabled us to see the everyday forms of resistance as an integral part of the urban, and as an everyday form of contention and contestation regarding how urban spaces are used, how activities are organized and negotiated, and how meanings are constructed.

But beyond ordinary acts of resistance or non-compliance, how can guerrilla urbanism contribute to substantive changes in planning practices or the political system? More recently, I have been examining the possible linkages between everyday spatial practices and strategic, organized resistance. In my chapter in Public Space Unbound (Knierbein and Viderman 2018), I examine a three-stage process of rupturing, accreting, and bridging: Rupturing refers to the way everyday insurgent actions create disruptions or openings in the hegemonic structure of the city and set the stage for potential, transformative actions; accreting signifies the way these everyday insurgent acts often can aggregate, multiply, reproduce and eventually become a force to be reckoned with, despite their modest or even insignificant beginning; lastly, bridging represents the process in which activists, non-profits, and other intermediaries facilitate and help transform everyday acts of individuals and small groups into forces of political and practical significance (Hou 2018). It is through these processes that, I argue, everyday insurgencies can overcome their limits in confronting dominant power or hierarchy. They represent the formation of consciousness in the struggle against injustice, as well as intentional, strategic actions to engage in resistance and produce structural changes, something that Dikeç (2001) and Albrechts (2003), respectively, argue as the required conditions for emancipation.

\section{Cases and narratives from six cities}

This special issue seeks to build upon this body of work and develop ways through which we can examine the mechanisms and implications of guerrilla urbanism more critically and productively. Specifically, we are interested in understanding how short-term, unsanctioned, and unscripted activities can begin to intersect with sustained, organized actions of resistance that lead to substantive and transformative outcomes. We hope that by understanding these processes better, we can begin to see guerrilla urbanism not only as a form of everyday, ordinary actions (which are still criti$\mathrm{cal}$ as a form of counter-hegemonic struggles and efforts to improve one's livelihood), but also as part of broader contentions and contestations that question the predominant model of urban development, planning, and placemaking, a process that engages a wide variety of individuals and groups well beyond the professional and institutional actors.

The examination begins with the case of Can Batlló in Barcelona, a former factory located in a working-class neighborhood of La Bordeta in Barcelona. The neighborhood has struggled to claim the former factory as a public space as it was formally designated by the city but never realized. Through confrontation, unauthorized entry, and other forms of collective actions involving residents, students, and professionals, the neighborhood has succeeded in holding the city accountable and converting a part of the site into a collective space. Three processes are investigated here-autoconeixement (self-knowledge), autogestió (selfmanagement), and autoconstrucció (self-construction) that are critical in linking short-term actions to long-term, organized struggles, and management of the space. Based on the case, David de la Peña argues that "tactical approaches to the city may also be deployed within a larger strategic framework that allows time for meaningful engagement, deliberative processes, and the promotion of craft and expertise." Contrary to the appeal of short-term actions, actual and sustained outcomes required long-term coordination, collaboration, and commitment between neighborhood residents and volunteers.

On São Paulo, Daniela Sandler contrasts two modes of grassroots urbanism, one representing struggles of disenfranchised social groups that reside in the urban periphery, and the other the design-focused forms of creative placemaking that inadvertently contribute to the process of upgrading and exclusion in the city center, despite the stated desire for diversity and openness. Using a geospatial mapping analysis, the study uncovers a substantial number of initiatives in the peripheral areas of the city. Distinct from their counterparts in the city center, these bottom-up initiatives (focusing primarily on arts programs, education, and social identities) highlight the role of culture in urbanism and the social production of space. More than just physical transformations, they represent a form of cultural struggle, a struggle for mobility, subjectivity, and self-determination that reflects the conditions of the periphery and the aspirations of its young inhabitants.

In Hong Kong, Minna Valjakka addresses artistic practices as a form of resistance through the hacking of existing urban environments. She highlights two specific cases that differ dramatically in scale, from transforming street corners to appropriating one of the city's newest and most prominent skyscrapers. The two cases differ also in technique, from urban knitting to advanced digital installation. In contrast to the common association of hacking with vandalizing, Valjakka argues that these practices contribute to the making of urban resilience by building political awareness and solidarity, and fostering new subjectivities and belonging while deconstructing the political and spatial norms. They create physical and discursive sites 
for political and social engagement. In doing so, her analysis departs from the instrumentalized view of art and culture that serves primarily the economic and political agenda of the creative city, an institutional context for many recent tactical urban interventions.

The following two articles focus on cases in drastically different urban contexts in the United States, both undergoing profound transformations. First, Daniel Campo examines how unsanctioned uses of former industrial sites led to new opportunities and ways in re-envisioning their rehabilitation. More specifically, he asks whether guerrilla actors can be agents of insurgent design that "break the trajectory of technocratic or growth coalition dominated development practice?" By examining the cases of the Carrie Blast Furnaces just outside Pittsburg and the Packard Automobile Factory in Detroit, the study found that the insurgent actors (including graffiti and installation artists, photographers, explorers, naturalists, partiers, etc.) have played a significant role in the preservation of the sites otherwise slated for demolition. However, their impact beyond physical conservation and interim uses may still be limited with the influx of global capital and the local economic development agenda. In Los Angeles, Jonathan Crisman and Annette Kim also compared two cases of guerrilla urbanism - the ubiquitous street vending by mostly immigrant vendors and antagonistic tactics deployed by anti-gentrification activists against new businesses in Boyle Heights. They argue that these guerrilla actions, at best, can be a catalyst that brings attention to a problem and initiates a process for social change. Yet, their impacts may be limited or short-lived if they are disengaged from political organizing.

The special issue then returns to Barcelona where the case of Plataforma de Afectados por La Hipoteca (PAH, or Platform for Mortgage-affected People) is examined. By investigating how activists in Barcelona help evicted families and groups reoccupy buildings and empty bank offices, Tihomir Viderman and Sabine Knierbein look beyond guerrilla urban actions as framed only by agonistic pluralism (Mouffe 2000) but instead approach them as affective encounters. Specifically, they examine how such practices "put affect and bodily encounters center stage in the production of political places for ethical interactions with the others." In disrupting established and routinized dynamics of urban spaces and creating a "lived counter space," they produced tangible outcomes that provide relief to people and communities in need of support.

\section{Findings and lessons}

While addressing the common theme of guerrilla urbanism, each of these case studies has engaged with the materials through a particular discursive lens. They include critiques of tactical urbanism (de la Peña), grassroot urbanism as a cultural struggle (Sandler), urban hacking and cultural resilience (Valjakka), reuse of postindustrial sites (Campo), property rights (Crisman and Kim), and guerrilla urbanism as sites of affective encounters (Viderman and Knierbein). The studies also speak to the different social and political contexts from the duality of center and periphery in São Paulo to the Rustbelt in the United States, the political tensions in Hong Kong, gentrification in Los Angeles, and impact of austerity policies in Barcelona and beyond. In spite of these differences, a few common threads and distinct lessons have emerged that suggest broader implications of these cases concerning the dynamics of everyday struggles and organized resistance in shaping specific urban processes and agenda.

\section{Ruptures $>$ openings $>$ transformation}

From the cases of Carrie Furnaces and Packard Plant to digital hijacking in Hong Kong, it's clear that unsanctioned actions have a unique capacity to create openings in the otherwise planned (and unplanned) urban spaces for new functions, programs, meanings, and possibilities. At the two postindustrial sites, artists and urban explorers have transformed abandoned facilities into productive landscapes of discovery and artistic manifestations. Despite the contrasting outcomes in terms of public stewardship vs. private ventures, the unsanctioned activities have opened new possibilities for the respective sites in ways that could not have been facilitated through a normative planning and design process. Similarly, in Hong Kong, the digital hijacking of the Human Vibration exhibition opened up an intense public debate about ethics and censorship, an instance of political debate and exchange that can be seen as contributing to the dynamics of cultural resilience in Hong Kong, a process (including the online countdown clock) that has outlived the exhibition. In all of these instances, guerrilla actions create a necessary condition for a long-term process to unfold that shapes how cities and urban spaces function. Without the unsanctioned actions, such processes and outcomes including physical manifestations would not have been possible. Such processes begin to suggest how practices of resistance can intersect with formalized institutions that govern urban design.

\section{Between overt and covert actions}

Guerrilla urban struggles adopt a variety of forms with shifting degrees of overtness and covertness. Among the cases examined in this special issue, they range from the contentious anti-gentrification tactics in Boyle Heights to urban knitting in Hong Kong. Each is powerful and significant in its own way. In Boyle Heights, while the efficacy and ethics 
of such actions are debated, even the side of the community that has been criticized for being too passive acknowledge that the overt, in-the-face, guerrilla tactics did bring the necessary attention to the impact of gentrification in the neighborhood. In Hong Kong, while the acts of urban knitting may seem trivial, mundane, and therefore insignificant, the activities, performed in public, have brought together individuals in ways that would not be possible through a formal community engagement process. In other cases, however, the implicitness or even invisibility of the actions and actors was necessary and desirable, echoing what others including Scott (1985) and Perera (2009) have described as an essential characteristic of everyday struggles. In Pittsburgh's Carrie Furnaces, for instance, it was necessary in the beginning to avoid attention to trespassing and the unsanctioned art installation, in order for these activities to thrive under the radar. Still, in other cases, it may become necessary to turn typically hidden and private struggles into open confrontations and collective defiance, as in the case of the Platform of Mortgage-affected People in Barcelona that mobilized the public against individual evictions. Rather than describing guerrilla resistance as having one tendency or another, it is important that we recognize its fluid nature in response to the specific contexts and necessities.

\section{From everyday struggles to organized resistance}

A central question in this special issue concerns the linkages between guerrilla struggles and longer-term, organized actions. The cases herein have illuminated such linkages and connections. In the case of Can Batlló in Barcelona, the self-organized processes in forms of autoconeixement (self-knowledge), autogestió (Self-management), and autoconstrucció (Self-construction) are linked with sustained organizing at the community level with the help of partnering actors. Their close connections have been responsible for the substantive and transformative outcomes. Similarly, in the case of property conflicts in Boyle Heights, Kim and Crisman argue that "when guerrilla urbanism is not embedded in a larger process of political organizing and institutional engagement, it remains ineffective in addressing the structural forces which lead to spatial injustice and social inequity." However, political organizing alone may not be sufficient. The linkages between everyday struggles, organized actions, and substantive outcomes may further require the presence of political opportunities, as in the case of street vendors in Los Angeles where the concerns for undocumented immigrant vendors threatened by Federal actions suddenly shifted the political dynamic and resulted in the public support for decriminalizing the activities.

The cases here also suggest that everyday struggles are not necessarily immune to or required to remove themselves from institutional engagement. For example, the self-organized art and culture groups in the periphery of São Paulo have made use of public funding to sustain their activities. Similarly, the case of digital hacking in Hong Kong took place in the context of a sanctioned art festival. One may argue that the parasitic nature of guerrilla urbanism is one of its greatest assets, one that can puncture and subvert the agenda of neoliberal urban governance. This represents perhaps another way through which guerrilla actions can intersect with urban design (in its institutionalized form) serving as the host in a parasitic relationship.

As snapshots of selected cases around the world, the findings here are by no means exhaustive or generalizable. Additional interpretations are certainly possible beyond those presented here. Nevertheless, even in their limited scope, these findings echo and reinforce some of the arguments presented elsewhere in the current body of literature particularly concerning the unspoken nature of transgressive actions as practiced by the subaltern subjects and the progression from informal activities to organized actions. In some cases, they have introduced additional complexity and nuances that are important in enriching our current understanding, particularly with regard to the scalability of guerrilla actions and the intersections with organized resistance and institutionalized practices.

\section{Implications for urban design discourses and practices}

Urban design, or more broadly the making of cities and urban places, is a field of practices that involve and impact a wide variety of actors and processes, some formal and some not. From institutional actors to communities and individuals, from planning, design, development, and management to everyday uses and adaptations by the public, urban design resides in a complex sphere of actions and reactions with no clear boundaries or absolute beginnings and ends, contrary to its common perception as a professional practice with well-defined parameters. Understanding the significance and characteristics of unsanctioned and unscripted spatial practices is an important step in comprehending the full complexity of these processes. At the epistemological level, such understanding allows us to critique practices of urban design as a profession. At the practical level, a stronger understanding allows us to better engage, respond to, and even leverage these insurgent practices for transformative outcomes. For citizens and communities at large, a better understanding of the significance of unsanctioned and unscripted actions would allow them to become aware of their capacity and agency in shaping the built environments, including the way those environments are used, received, and experienced. Whether agonistic or affective, it is through these unscripted processes of engagement that possibilities for change in the 
urban environments can become open and malleable. It might be useful to add that for a profession long influenced and informed by the work of Jane Jacobs and William H. Whyte, it should not be hard to understand the implications of such unsanctioned and unscripted urban spatial practices.

Lastly, it is important to understand that as urban design becomes a part of the system that serves the forces of speculative redevelopment, gentrification, and exclusion, the unsanctioned and unscripted can be seen as a form of resistance, as insurgent acts against the accepted norms and politico-economic hegemony. Guerrilla urbanism in this light represents the contention and contestation in urban life and the struggles of the oppressed. The unsanctioned and unscripted can be simultaneously tools of survival as well as actions by those seeking alternatives to the current systems and practices. They highlight specific contentions and challenges as well as opportunities facing communities and places. They manifest the agency and power of individuals and collectives in resisting as well as constructing alternative futures. This special issue is intended to be a step forward in producing the knowledge necessary for us to critically examine the processes of contention and contestation and the respective roles of formal and informal actors. While the investigation here may stop short of providing and articulating the normative steps for engaging in the continued contention and contestation, this introductory article outlines a few reflections on the specific characteristics and processes that may inform future actions.

In this issue, the refocus on guerrilla urbanism and the significance of unsanctioned and unscripted actions seeks to highlight the critical importance of the social and political in urban design. It is undeniable that urban design is a social and political act, though disguised often as a technocratic practice. At a fundamental level, guerrilla urbanism represents disruptions and challenges to the rationalist, technocratic, and postpolitical paradigm of planning and design that tends to dominate professional discourses and practices. Whereas tactical urbanism may be seen as appropriating the unsanctioned and unscripted into the technocratic repertoire of design professionals and institutional actors, guerrilla urbanism, on the other hand, presents the unsanctioned and unscripted as disruptions and challenges to the system. They serve as critical reminders of the limits (and possibilities) of urban design as a social and professional practice, and the power of individuals and collectives in destabilizing and disrupting the system while constructing alternative futures, all through the practices of resistance.

Acknowledgements Many thanks to Urban Design International editors Mahyar Arefi and Noha Nasser for their invitation back in 2016 to organize and curate this special issue and the support from the journal staff during the long process. I am grateful to the contributing authors for their responsiveness and the anonymous reviewers for their constructive comments and suggestions, and to Gordon Douglas for accepting the invitation to provide a critical commentary that deepens the dialogue. This opportunity to revisit and expand upon the notion of guerrilla urbanism a decade since the term was introduced could not have been realized without their wisdom and generosity.

\section{References}

Albrechts, L. 2003. Planning and Power: Towards an Emancipatory Planning Approach. Environment and Planning C: Government and Policy 21 (6): 905-924.

Bayat, A. 2013. Life as Politics: How Ordinary People Change the Middle East. Stanford: Stanford University Press.

Bishop, P., and L. Williams. 2012. The Temporary City. London and New York: Routledge.

Brenner, N., and N. Theodore (eds.). 2003. Space of Neoliberalism: Urban Restructuring in North America and Western Europe. New York: Wiley-Blackwell.

Campo, D. 2016. Book Review: Tactical Urbanism: Short-Term Action for Long-Term Change. Journal of Urban Design 21 (3): 388-390.

Chalana, M., and J. Hou. 2016. Epilogue: Sites of questions, contestation, and resistance. In Messy Urbanism: Understanding the 'Other' Cities of Asia, ed. M. Chalana and J. Hou, 238-243. Hong Kong: Hong Kong University Press.

Chase, J., M. Crawford, and J. Kaliski (eds.). 1999. Everyday Urbanism. New York: The Monacelli Press.

De Certeau, M. 1984. The Practice of Everyday Life. Berkeley: University of California Press.

Dikeç, M. 2001. Justice and Spatial Imagination. Environment and Planning A 33 (10): 1785-1805.

Douglas, G.C.C. 2014. Do-it-Yourself Urban Design: The Social Practice of Informal "Improvement" Through Unauthorized Alteration. City \& Community 13 (1): 5-25.

Douglas, G.C.C. 2018. The Do-It-Yourself City: Legitimacy and Inequality in DIY Urbanism. New York: Oxford University Press.

Finn, D. 2014. DIY Urbanism: Implications for Cities. Journal of Urbanism 7 (4): 381-398.

Foucault, M. 1977. Discipline and Punish. New York: Pantheon Books.

Franck, K., and Q. Stevens. 2007. Loose Space: Possibility and Diversity in Urban Life. London and New York: Routledge.

Hayden, F., and R. Temel. 2006. Temporary Urban Spaces: Concepts for the Use of City Spaces. Basel: Birkhäuser.

Holston, J. 1998. Spaces of insurgent citizenship. In Making the Invisible Visible: A Multicultural Planning History, ed. L. Sandercock, 37-56. Berkeley: University of California Press.

Hou, J. (ed.). 2010. Insurgent Public Space: Guerrilla Urbanism and the Remaking of Contemporary Cities. London and New York: Routledge.

Hou, J. (ed.). 2013. Transcultural Cities: Border-Crossing and Placemaking. London and New York: Routledge.

Hou, J. 2016. Everyday urban flux: Temporary urbanism in East Asia as insurgent planning. In Messy Urbanism: Understanding the 'Other' Cities of Asia, ed. M. Chalana and J. Hou, 193-214. Hong Kong: Hong Kong University Press.

Hou, J. 2018. Rupturing, accreting and bridging: Everyday insurgencies and emancipatory city-making in East Asia. In Public Space Unbound: Urban Emancipation and the Post-Political Condition, ed. S. Knierbein and T. Viderman, 85-98. London and New York: Routledge.

Hou, J., and M. Chalana. 2016. Untangling the "Messy" Asian City. In Messy Urbanism: Understanding the 'Other' Cities of Asia, ed. M. Chalana and J. Hou, 1-21. Hong Kong: Hong Kong University Press. 
Iveson, K. 2013. Cities with the City: Do-it-Yourself Urbanism and the Right to the City. International Journal of Urban and Regional Research 37 (3): 941-956.

Knierbein, S., and T. Viderman (eds.). 2018. Public Space Unbound: Urban Emancipation and the Post-Political Condition. London and New York: Routledge.

Lydon, M., and A. Garcia. 2015. Tactical Urbanism: Short-Term Actions for Long-term Change. Washington, DC: Island Press.

Miraftab, F. 2004. Invited and Invented Spaces of Participation: Neoliberal Citizenship and Feminists' Expanded Notion of Politics. Wagadu 1: 1-17.

Miraftab, F. 2009. Insurgent planning: Situating radical planning in the Global South. Planning Theory 8 (1): 51-75.

Mouffe, C. 2000. The Democratic Paradox. London and New York: Verso.

Mould, O. 2014. Tactical Urbanism: The New Vernacular of the Creative City. Geography Compass 8 (8): 529-539.

Overmeyer, K. 2007. Urban Pioneers: Temporary Uses and Urban Development in Berlin. Berlin: Jovis.

Perera, N. 2009. People's Spaces: Familiarization, Subject Formation and Emergent Spaces in Colombo. Planning Theory 8 (1): 51-75.

Scott, J.C. 1985. Weapons of the Weak: Everyday Forms of Peasant Resistance. New Haven and London: Yale University Press.
Scott, J.C. 1989. Everyday Forms of Resistance. The Copenhagen Journal of Asian Studies 4: 33-62.

Silva, P. 2016. Tactical Urbanism: Towards an Evolutionary Cities' Approach. Environment and Planning B: Urban Analytics and City Science 43 (6): 1040-1051.

Vallance, S., A. Dupuis, D. Thorns, and S. Edwards. 2017. Temporary Use and the Onto-Politics of 'Public' Space. Cities: The International Journal of Urban Policy and Planning 70: 83-90.

Von Seggern, H., and J. Werner. 2008. Focus: Urban landscapes, designing and innovation strategies. In Creating Knowledge: Innovation Strategies for Designing Urban Landscapes, ed. H. Seggern, J. Werner, and L. Grosse-Bächle, 196-209. Berlin: Jovis. Webb, D. 2018. Tactical Urbanism: Delineating a Critical Praxis. Planning Theory \& Practice 19 (1): 58-73.

Publisher's Note Springer Nature remains neutral with regard to jurisdictional claims in published maps and institutional affiliations. 